\title{
Evaluation of the growing and fruit bearing characteristics of the 'Lapins' sweet cherry cultivar grafted on rootstocks with different vigor
}

\author{
Csihon Á., Bicskei D. K., Dremák P. \& Gonda I. \\ University of Debrecen, Faculty of the Agricultural and Food Sciences and Environmental Management, Institute of Horticulture \\ 138. Böszörményi str., Debrecen, H-4032, Hungary, author for correspondence: Csihon, Á. (csihonadam@agr.unideb.hu)
}

\begin{abstract}
Summary: Sweet cherry is currently considered as a fruit with high interests. The amount of the produced yield is well saleable in the world and also in Hungary year by year, moreover often there is a shortage with the high quality fruits. Researches with the sweet cherry production focus on the intensity growing all over the world, namely the realization of producing with small trees ensuring high quality and quantity. In our examinations 'Lapins' sweet cherry cultivar was evaluated grafted on rootstocks with different vigor (Gisela 5, Gisela 6, Colt) at the University of Debrecen, Pallag Experimental Station. According to our results trees grafted on Colt rootstock can be described with very low yields due to the excessive high vigor. Trees with Gisela 5 and Gisela 6 rootstocks showed excessive high productivity, as size of the fruits did not reach the required values.
\end{abstract}

Csihon Á., Bicskei D. K., Dremák P., Gonda I. (2017): Evaluation of the growing and fruit bearing characteristics of the 'Lapins' sweet cherry cultivar grafted on rootstocks with different vigor. International Journal of Horticultural Science 23(1-4): 15-18. https://doi.org/10.31421/IJHS/23/14./1195

Key words: sweet cherry, rootstocks, cultivars, vegetative characteristics, generative accomplishment

\section{Introduction}

Sweet cherry production currently is one of the most prospective sectors of the fruit production. Yield can be sold with good prices year by year, as the world production is growing slowly. Sweet cherry belongs to the earliest ripening fruits, only strawberry means concurrency for it on the market. Thanks to its short growing season fruits are exposed to the environmental risks for a shorter period of time. Moreover due to the early ripening time high prices can be achieved on the market, as an off-season fruit (Kelemen \& Takács, 2015; Szabó, 2010).

In Hungary the annual production of sweet cherry is about $15000-18000$ tons, which is cultivated in 2800 hectares (FruitVeB, 2016), as the average yield per hectare is very low (5-6 tons/hectares). One of the main reasons of that the most of the orchards are cultivated with low density and traditional canopies. Meanwhile research focuses on the intensive sweet cherry growing and plant protection all over the world, thus small trees ensure good pest management and high quality and quantity (Gonda, 2012; Holb, 2006; Holb et al., 2011).

There was a common belief among sweet cherry producers over decades that the lack of the dwarfing rootstocks obstructed the spreading of the intensive orchards. Therefore the main aim of the breading all over the world was to produce dwarfing rootstocks (Webster, 1998; Callesen, 1998). Nowadays wide choice of these rootstocks is available for the producers (e.g. Gisela, Pi-Ku, Weiroot, MaxMa serial) thanks to mainly for the Western European and North American breeders (Balmer \& Blake, 2005; Robinson, 2005). Nevertheless their vegetative achievement can be different under diverse climate conditions, thus they should be tested for each production area (Lang, 2005).
In the domestic sweet cherry orchards more than $80 \%$ of the trees currently are grafted on Prunus avium or Prunus mahaleb rootstocks. New dwarfing rootstocks used in Europe are spreading slowly in the home cultivation, although their ratio is expected to grow in the future by spreading of the intensive orchards with high plant density. Namely dwarfing effect of the rootstocks has a greater role in the orchards with small canopy (Soltész et al., 2011).

In the domestic plantations for the present there are only few experiences with the Gisela rootstocks. Main advantage of the Gisela 5 and Gisela 6 rootstocks that they have significance dwarfing effect on the cultivars, however both of them are suggested to apply only in the production sites which have similar ecological conditions than their original breading place. Absence of cool, balanced climate can result that trees are not able to bear adequate fruit quality, as fruits are small and not competitive. In the case of Gisela 5 rootstock not only the fruits size, but the cropping surface can also decrease, as the ratio of inactive, bald parts of the canopy starts to grow (Bujdosó, 2010). Vigor of the Gisela 5 and Gisela 6 rootstocks is mainly depend on the production site, but their growth decrease only under dry climate and on barren soils (Soltész et al., 2011).

Application of Gisela rootstocks in many cases requires different approach than the usual practice. Pruning and fertilizing must serve the maintaining of the continuous growth. In certain years and with cultivars fruit thinning can be also required to reach the optimal fruit size. Under domestic circumstances from the Gisela rootstock series Gisela 5 and Gisela 6 are recommended to apply with self-incompatible cultivars on medium bound soils, if the orchard is irrigated. With self-pollinating cultivars Gisela 6 rootstock is proposed to graft (Kelemen \& Takács, 2015). 


\section{Materials and methods}

Place of the experiments is located at the University of Debrecen, Pallag Experimental Station. During our work beyond the fruit bearing parameters we aimed to evaluate the growing characteristics of the sweet cherry trees in detail, based on which suggestions can be made regarding the maintenance of canopies.

Ecological parameters of the experimental area:

- Mean temperature of the year: $10-11^{\circ} \mathrm{C}$,

- Sunshine hours: 1900-2050 hours/year,

- Precipitation: $530 \mathrm{~mm}$,

- $\mathrm{pH}$ of the soil: slightly acid, $\mathrm{pH}$ 6.5,

- Humus content: 0.8-1.0\%, light sandy loam,

- “Arany” number of heaviness: 25-27.

The experimental orchard was established in March of 2013. Planting material was one year old scion with highly developed, ramified roots came from the Netherlands. Trees were planted 5 $\mathrm{m} \times 2 \mathrm{~m}$, and slender spindle canopy was trained. Cultivar of the trees is 'Lapins' which were grafted on very weak (Gisela 5), weak (Gisela 6) and vigorous (Colt) rootstocks.

In the orchard plant protection is carried in accordance with the integrated management principles. Water supply is solved with dropping irrigation system. Trees are pruned once in a year, at the end of winter. Trellis system has not been installed next to the trees.

Our measurements besides the fruit bearing and fruit quality parameters focused on the growing characteristics of the trees, which determine basically the training and maintaining of the canopy. Each variant of rootstock x cultivar was represented by five trees, which were in randomized block design. Growing peculiarities were assessed in autumn of 2017, after leaf fall. Statistics were performed by ANOVA at $\mathrm{P}=0.05$ level using LSD test.

\section{Examined sweet cherry rootstocks}

Gisela 5 (Prunus cerasus $\times$ Prunus canescens): dwarfing rootstock with very week vigor. Available tree size is about 60$65 \%$ compared to the Prunus avium. It is sensitive to nutrition and water content of the soil and to the drought stress.

Gisela 6 (Prunus cerasus $\times$ Prunus canescens): dwarfing rootstock with week vigor. Available tree size is about $65-70 \%$ compared to the Prunus avium. Among the Gisela rootstocks it is less sensitive to the heat stress.

Colt (Prunus avium $\times$ Prunus pseudocerasus): hybrid of the Prunus avium with very strong vigor. Compatible with the cherry cultivars, time of turning to bearing is early, trees have a long life period. It tolerates well the high soil moisture, not sensitive to the root drowning, but it does not favor the dry soils.

\section{Examined sweet cherry cultivar}

'Lapins': self-pollinating cultivar, comes from Canada. Harvest period is in mid season. Fruit size is large $(28 \mathrm{~mm})$, globular, well-looking. It has high firmness, but it is sensible to cracking, and has less intensive aroma. Time of turning to bearing is late, but after that trees bear regularly and abundantly. Vigor of the trees is middle strong which have bad ramification ability.

\section{Results and discussion}

Parameters related with tree size of 'Lapins' sweet cherry cultivar is shown in Table 1. Trunk cross sectional area (TCSA) which can be considered as a complex index of the vegetative accomplishment reflects well the effect of the rootstocks on the vigor of the trees. Lowest trunk cross sectional area $\left(52.7 \mathrm{~cm}^{2}\right)$ was measured with Gisela 5 rootstock at the age of 5 years. Trees of Gisela 6 rootstock presented 36.3\% higher trunk thickness $\left(71.8 \mathrm{~cm}^{2}\right)$. Colt rootstock induced very strong growth, as TCSA is larger with $258 \%$ compared to the trees of Gisela 5.

Regarding the height trees with Gisela rootstock are close to 4 meter, as trees of Colt rootstock displayed excessive height $(4,8 \mathrm{~m})$.

Zahn-indexes (the ratio of the trunk thickness and the basic scaffold branches) was used to study the growing balance of the trees. In this regard it can be seen that all rootstock $x$ cultivar combinations showed higher indexes than the critical 0.5 value. The scale of this overthickening is smaller with Gisela rootstocks (0.61-0.66) and larger with Colt rootstock (0.83).

Table 1. Parameters related with tree size of 'Lapins' sweet cherry cultivar on five years old trees (Debrecen - Pallag, 2017)

\begin{tabular}{|l|c|c|c|}
\hline & $\begin{array}{c}\text { TCSA } \\
\left(\mathrm{cm}^{2}\right)\end{array}$ & $\begin{array}{c}\text { Tree height } \\
(\mathrm{cm})\end{array}$ & Zahn-index \\
\hline Gisela 5 & 52.7 & 397 & 0.61 \\
\hline Gisela 6 & 71.8 & 397 & 0.66 \\
\hline Colt & 136.1 & 477 & 0.83 \\
\hline LSD5\% & 4.8 & 31 & 0.13 \\
\hline
\end{tabular}

Data related with generative achievement is included in Table 2. One main risk of the application of the Gisela rootstocks is the proneness of oversetting which is confirmed by our measurements. Namely these rootstocks presented very high $53-55 \%$ fruit setting, as in the case of Colt rootstock $18 \%$ of the flowers became fruits. Accordingly harvested yield was larger with Gisela rootstocks (7.8-10.1 kg/tree), while trees of Colt produced very low amount of fruits $(2.7 \mathrm{~kg} / \mathrm{tree})$. These differences are more evident if the yield is compared to the trunk thickness $\left(142-148 \mathrm{~g} / \mathrm{cm}^{2}\right.$, respectively $\left.20 \mathrm{~g} / \mathrm{cm}^{2}\right)$.

Table 2. Generative achievement of 'Lapins' sweet cherry cultivar (Debrecen - Pallag, 2017)

\begin{tabular}{|l|c|c|c|c|c|}
\hline & $\begin{array}{c}\text { Fruit } \\
\text { setting } \\
(\%)\end{array}$ & $\begin{array}{c}\text { Yield } \\
(\mathrm{kg} / \\
\text { tree })\end{array}$ & $\begin{array}{c}\text { Yield/ } \\
\text { TCSA } \\
\left(\mathrm{g} / \mathrm{cm}^{2}\right)\end{array}$ & $\begin{array}{c}\text { Fruit } \\
\text { size } \\
(\mathrm{mm})\end{array}$ & $\begin{array}{c}\text { Fruit } \\
\text { weight } \\
(\mathrm{g})^{*}\end{array}$ \\
\hline Gisela 5 & 55 & 7.8 & 148 & 23.9 & 7.0 \\
\hline Gisela 6 & 53 & 10.1 & 142 & 21.4 & 6.0 \\
\hline Colt & 18 & 2.7 & 20 & 27.2 & 10.1 \\
\hline LSD $_{5 \%}$ & 9.7 & 4.0 & 34 & - & - \\
\hline
\end{tabular}

Regarding the fruit size the notably overloaded trees of Gisela 5 and Gisela 6 showed values of 21.4-23.9 mm, as neither of them could reach $26 \mathrm{~mm}$ diameter required by the fresh market. Trees of Colt satisfied this criteria with $27.2 \mathrm{~mm}$ diameter, but its yield is very low.

Thickness of the central axis in different height zones, namely the tapering dynamics of the central axis is a decisive factor for the tree height. Figure 1 shows that trees of Colt rootstock has much larger axis thickness similarly to the trunk 
thickness. Difference is about twofold in each measured point compared to the trees of Gisela 6. Axis starts to taper fast in the lower region (100-150 cm zone), as the decrease is more steady later. There is a $25-27 \%$ difference in the axis thickness at 100 $150 \mathrm{~cm}$ height between Gisela 5 and Gisela 6 trees, which difference is equalized in the higher zones. Based on the data it can be stated, that the tapering dynamics of the central axis does not hamper to reach and maintain the optimal tree height.

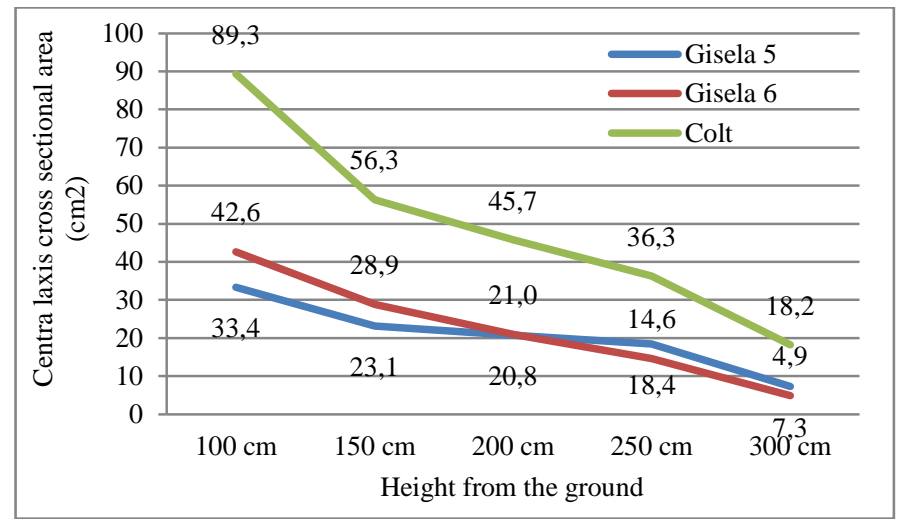

Figure 1. Central axis cross sectional area in different height zones (Debrecen - Pallag, 2017)

To form the optimal canopy structure proportional distribution of the branches on the central axis is required. In the case of the 'Lapins' cultivar excessive low number of branches (0-3.7 pieces) were counted in each height zones of the axis regardless the rootstocks (Figure 2). This phenomenon shows the extreme bad ramification ability of the cultivar. Higher number of branches (1.7-3.7 pieces) is found on the trees of Colt rootstock in the lower part of the canopy $(50-150 \mathrm{~cm})$. In the case of the Gisela 5 and Gisela 6 trees practically total lack of the branches was observed in the $100-150 \mathrm{~cm}$ height region, directly above the main basal scaffold branches.

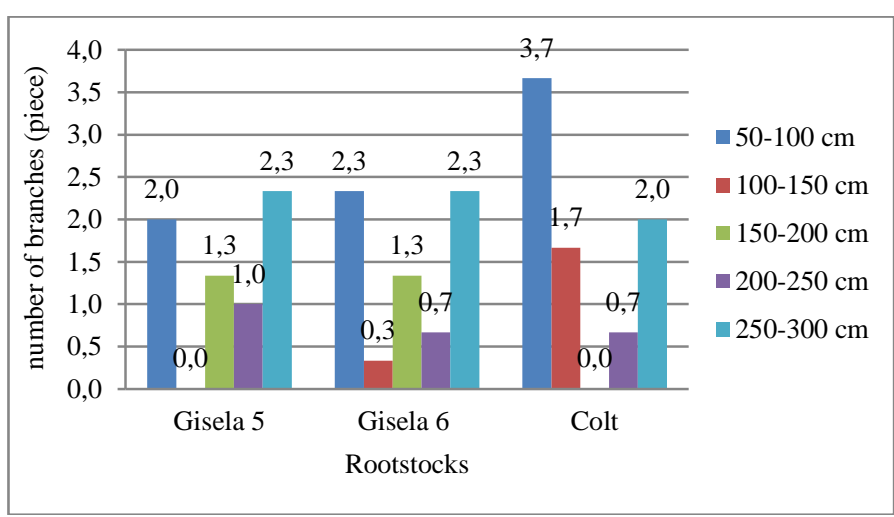

Figure 2. Number of the branches emerging from the central axis in different height zones (Debrecen - Pallag, 2017)

Concerning the thickness of the branches of central axis (Figure 3) it can be seen, that in the most cases the tendency for the spindle canopies prevails, as thickness of the branches decreasing from the bottom to the top. In certain points can be observed different trend. On the trees with Gisela rootstocks thickness of the branches increases in the 150-300 cm height zones, contrary to the usual. Thicker branches were measured with Gisela 6 and Colt rootstocks in the 200-250 cm height region.

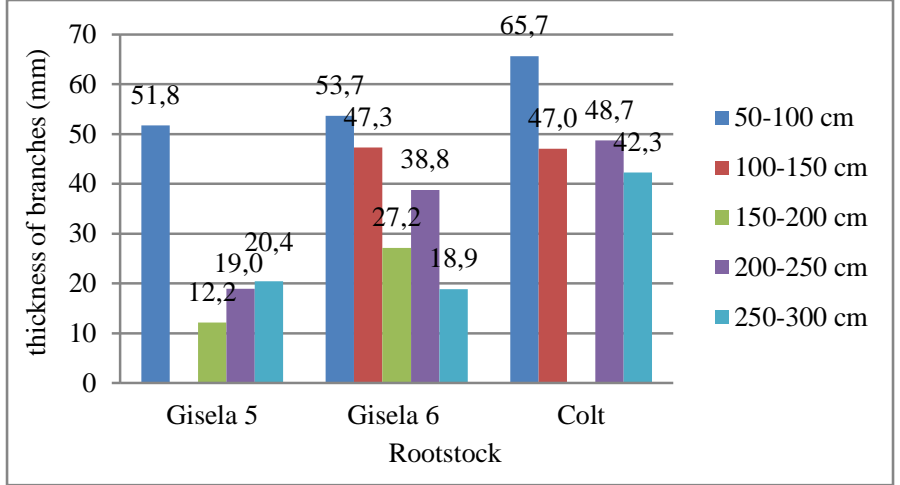

Figure 3. Thickness of the branches emerging from the central axis in different height zones (Debrecen - Pallag, 2017)

Most of the cherry fruits develop from its typical fruit bearing parts, the bouquets of spurs. Its number and density determine basically the available yield, so their quantifying shows well the productivity of the trees. Table 3 presents the number of the bouquets of spurs formed on the central axis which is relevant in term of the fruit quality, as near to the transport tissues trees bear well developed fruits. Based on the data it can be seen, that in each height region of the axis the least bouquets of spurs developed on the trees of Colt rootstock (0.7-2.3 pieces), as Gisela rootstocks displayed higher values (2.7-10.3 pieces).

Table 3: Number of bouquets of spurs in the central axis in different height zones (Debrecen - Pallag, 2017)

\begin{tabular}{|l|c|c|c|c|}
\hline & $\begin{array}{c}100-150 \\
\mathrm{~cm}\end{array}$ & $\begin{array}{c}150-200 \\
\mathrm{~cm}\end{array}$ & $\begin{array}{c}200-250 \\
\mathrm{~cm}\end{array}$ & $\begin{array}{c}250-300 \\
\mathrm{~cm}\end{array}$ \\
\hline Gisela 5 & 0.0 & 5.3 & 6.3 & 1.3 \\
\hline Gisela 6 & 2.7 & 8.0 & 8.0 & 10.3 \\
\hline Colt & 1.3 & 2.3 & 1.3 & 0.7 \\
\hline
\end{tabular}

Most part of the fruits develop on bouquets of spurs of 2-4 years old branches. Their density mainly depend on the vigor of the rootstocks, the characteristics of the cultivar and the scale of the balding processes related to the age of the trees. Regarding the number of bouquets of spurs calculated to running-meter 'Lapins' cultivar showed spectacular differences on different rootstocks (Table 4). Highest cropping part density of the 2-4 years old branches was measured on the trees of Gisela 6 (14.026.2 pieces $/ \mathrm{m}$ ). Between Gisela 5 and Colt rootstocks previous one presented higher values on the two years old parts $(22.3$ pieces $/ \mathrm{m}$ ), as their difference is equalized on the 3-4 years old branches.

Higher productivity state ensured by Gisela 6 rootstock manifests also in the number of the cropping parts calculated to the branch cross sectional area (BCSA), as these trees showed the highest density $\left(5.8\right.$ pieces $\left./ \mathrm{cm}^{2}\right)$ of bouquets of spurs (Table $5)$. In the case of Gisela 5 smaller values $\left(2.33\right.$ pieces $\left./ \mathrm{cm}^{2}\right)$ were measured compared to the Colt rootstock (3.99 pieces $\left./ \mathrm{cm}^{2}\right)$. The strong growth inducing effect of the Colt rootstock can be detected also in the number of shoots and sum of shoots length, as their values are about twofold compared to the Gisela 6 rootstock. Meanwhile the average shoot length is the same with trees of Gisela 6 and Colt rootstock $(59-60 \mathrm{~cm})$. Gisela 5 rootstock reached the lowest values in all examined parameters. 
Table 4. Number of bouquets of spurs on the branches with different age (Debrecen - Pallag, 2017)

\begin{tabular}{|l|c|c|c|}
\hline & $\begin{array}{c}\text { On two years } \\
\text { old branches } \\
\text { (pieces/m) }\end{array}$ & $\begin{array}{c}\text { On three years } \\
\text { old branches } \\
\text { (pieces/m) }\end{array}$ & $\begin{array}{c}\text { On four years old } \\
\text { branches } \\
\text { (pieces/m) }\end{array}$ \\
\hline Gisela 5 & 22.3 & 15.6 & 7.2 \\
\hline Gisela 6 & 26.2 & 21.1 & 14.0 \\
\hline Colt & 18.5 & 17.4 & 8.1 \\
\hline
\end{tabular}

Table 5. Fruit bearing parts of the basal scaffold branches (Debrecen - Pallag, 2017)

\begin{tabular}{|l|c|c|c|c|}
\hline & $\begin{array}{c}\text { Number of } \\
\text { bouquets of } \\
\text { spurs/BCSA } \\
\left(\text { piece/cm }{ }^{2}\right)\end{array}$ & $\begin{array}{c}\text { Number of } \\
\text { shoots/ } \\
\text { BCSA } \\
(\text { piece/cm }\end{array}$ & $\begin{array}{c}\text { Sum of shoots } \\
\text { length/ BCSA } \\
\left(\mathrm{cm} / \mathrm{cm}^{2}\right)\end{array}$ & $\begin{array}{c}\text { Length } \\
\text { of shoots } \\
(\mathrm{cm})\end{array}$ \\
\hline Gisela 5 & 2.33 & 0.43 & 19.5 & 49 \\
\hline Gisela 6 & 5.80 & 0.59 & 34.8 & 60 \\
\hline Colt & 3.99 & 1.15 & 69.5 & 59 \\
\hline
\end{tabular}

Table 6. Parameters of the shoots (Debrecen - Pallag, 2017)

\begin{tabular}{|l|c|c|c|c|c|c|}
\hline & $\begin{array}{c}\text { Bottom } \\
\text { thickness } \\
(\mathrm{mm})\end{array}$ & $\begin{array}{c}\text { Middle } \\
\text { thickness } \\
(\mathrm{mm})\end{array}$ & $\begin{array}{c}\text { Upper } \\
\text { thickness } \\
(\mathrm{mm})\end{array}$ & $\begin{array}{c}\text { Average } \\
\text { thickness } \\
(\mathrm{mm})\end{array}$ & $\begin{array}{c}\text { Volume of } \\
\text { the shoots } \\
\left(\mathrm{cm}^{3}\right)\end{array}$ & $\begin{array}{c}\text { Number of the } \\
\text { buds/shoots } \\
(\mathrm{piece} / \mathrm{m})\end{array}$ \\
\hline Gisela 5 & 7.3 & 5.9 & 4.6 & 5.9 & 13.5 & 55.8 \\
\hline Gisela 6 & 7.9 & 6.5 & 4.9 & 6.4 & 19.4 & 45.3 \\
\hline Colt & 8.6 & 6.4 & 4.6 & 6.5 & 19.8 & 34.2 \\
\hline
\end{tabular}

Thickness and volume of the shoots also describe well the vigor of the trees (Table 6). In this term lower values were recorded with Gisela $5\left(5.9 \mathrm{~mm}\right.$ average thickness, $13.5 \mathrm{~cm}^{3}$ volume), as parameters of Gisela 6 and Colt are practically equal (6.4-6.5 mm thickness, 19.4-19.8 $\mathrm{cm}^{3}$ volume). Bud number of the shoots shows opposite orders, as shoots of Gisela 5 with the shortest length developed the most buds calculated to one running-meter (55.8 pieces $/ \mathrm{m})$. Most of these buds are located at the basal part of the shoots including flower buds. Trees of Gisela 6 produced 23\% less buds on the shoots, while values of Colt rootstock are lower with $63 \%$.

\section{Conclusions}

According to our result it can be stated that the rootstocks with different vigor (Gisela 5, Gisela 6, Colt) had significant effect on the vegetative and generative accomplishment of the 5 years old trees of 'Lapins' cultivar. Strong growth inducing effect of the Colt rootstock prevailed in all examined parameters. This resulted in larger tree sizes, branches tend to overthickening, higher number of twigs. Due to the larger canopy the flower bud load of the trees is weaker. Accordingly trees of Colt rootstock produced huge amount of wood, but very low amount of yield $\left(2.7 \mathrm{~kg} / \mathrm{tree}, 20 \mathrm{~g} / \mathrm{cm}^{2}\right)$.

Dwarfing rootstocks (Gisela 5 and Gisela 6) developed smaller tree size and higher productivity (7.8-10.1 kg/tree, 142$148 \mathrm{~g} / \mathrm{cm}^{2}$ ). However thanks to the notable oversetting fruit size decreased significantly $(21.4-23.9 \mathrm{~mm})$, as fruits could not satisfy the criteria of the fresh market.

'Lapins' cultivar presented very week ramification ability on each rootstocks, as specific fitotechnical interventions inducing the budding (banding down the branches, nicking above the bud, cutting back) have a significant role during the training of the canopy.

Summarizing it can be stated that, under the ecological conditions of the experimental site (lower Humus content, prone to be arid) neither Colt nor Gisela 5 and 6 rootstocks could ensure high yields and adequate quality in the same time. Colt rootstock can be described with extreme vegetative accomplishment, as Gisela 5 and 6 rootstocks presented excessive generative achievement.

\section{Acknowledgements}

Supported BY the ÚNKP-17-4 New National Excellence Program of the Ministry of Human Capacities”.

\section{References}

Balmer, M., Blake, M. (2005): Developments in high density sweet cherries in Germany. Acta Hort. 667: 273-278.

Bujdosó, G. (2010): Fontoljuk meg az alanyválasztást. Kertészet és Szőlészet 59(23): 8-9.

Callesen, O. (1998): Recent developments in cherry rootstocks research. Acta Hort. 468: 219-228.

Fruitveb (2016): A zöldség és gyümölcs ágazat helyzete Magyarországon. Fruitveb Magyar Zöldség-Gyümölcs Szakmaközi Szervezet és Terméktanács. Budapest, 2016.

Gonda, I. (2012): Intenzív cseresznye müvelési rendszerek itthon és a nagyvilágban. DE AGTC MÉK Kertészettudományi Intézet, Gonda István Bt. 117 p.

Holb, I. J. (2006): Possibilities of brown rot management in organic stone fruit production in Hungary. International Journal of Horticultural Science 12(3): 87-92.

Holb I J, Vámos A, Lakatos P, Gáll J M, Abonyi F (2011): Some aspects of reduced disease management against Blumeriella jaapii in sour cherry production. International Journal of Horticultural Science 17(1-2): 49-52.

Kelemen, P., Takács, F. (2015): A cseresznye piaci helyzete, kilátásai, a termesztés fejlesztési lehetőségei és korlátai. Zöldség-Gyümölcs Piac és Technológia. 2015/március. 33-36. p.

Lang, G. A. (2005): Underlying principles of high density sweet cherry production. Acta Hort. 667: 325-336.

Robinson, T. L. (2005): Developments in high density sweet cherry pruning and training system around the world. Acta Hort. 667 (2): 269-272.

Soltész, M., Hilsendegen, P., Farkas, E. (2011): Cseresznye alanyok. In.: Intenzív cseresznyetermesztés. Szerk.: Nyéki, J., Soltész, M., Szabó, Z. Kiadja: Debreceni Egyetem, AGTC Kutatási és Fejlesztési Intézet, Kecskeméti Főiskolai Kar. 3140. p.

Szabó, Z. (2010): Tendenciák a világ cseresznyetermesztésében. Zöldség-Gyümölcs Piac és Technológia. 2010/június. 13-14. p.

Webster, A. D. (1998): Strategies for controlling the tree size of sweet cherry trees. Acta Hort. 410: 229-240. 